\title{
Acoustic Analysis as a Part of Risk Management
}

\author{
Michaela Balážiková*, Juraj Sinay \\ Technical University of Košice, Faculty of Mechanical Engineering, Department of Safety and Quality, Letná 9, 04200 Košice, \\ Slovak Republik
}

\section{BIOGRAPHICAL NOTES}

Michaela Balážiková, doc. Ing., PhD., born $5^{\text {th }}$ December 1976, graduated from the Technical University of Košice, Faculty of Manufacturing Technologies with a seat in Prešov, in the field of general mechanical engineering, in 2000. Current position: Assistant Professor. Specialization: Risk management, Acoustic risks management, Occupational safety and health, and Safety of technological systems. She has written more than 51 publications in the area of risks acoustics management, and participated as a team member in several national and international projects.

Juraj Sinay, DrSc., prof., Ing., PhD., born 18 ${ }^{\text {th }}$ December 1949; graduated from the Technical University of Košice, Faculty of Mechanical Engineering in 1973. Position: Professor, Head of the Department of Quality and Safety; Specialization: Risk management, Occupational safety and health, and Safety of technological systems. Member of the working group IVSS, Sektion Maschinenschutz based in Manheim, Germany. Member of Gesellschaft für Sicherheitswissenschaften (Society for Safety Sciences) VDI Wuppertal, Germany. Member of the Conference of German-speaking Professors of Transport Technology in Europe based in Berlin, Germany. He has authored several professional publications on occupational safety and management of risks related to machines and devices in the safety and security interface, and papers for numerous journals and conferences.

\section{KEY WORDS}

Acoustic risk management, Noise, Emerging risk

\begin{abstract}
The paper focuses on the area of risk management and includes a safety analysis of individual threats. Noise as a physical factor also belongs among individual hazards. In general, risk management is related to the architecture of an effective management of individual risks (principles, structure and processes), while the control of risk involves the application of this architecture to a particular risk; in this case, the acoustic risk. The paper describes a legislative framework concerning the safety and health protection at work as well as the safety of technical equipment with regard to obligations of the employer prescribed by law. An important part of the paper is the presentation of a guideline for prediction of acoustic risks by means of a system, which is specified for design of the low-noise machines. This methodology is an integrated part of safety analyses in the organisation and it is performed during the risk management process. A new method for proposal of the safe (low-noise) machine equipment is also described in the lecture, taking into consideration the legislative rules concerning the machine safety. Practical examples of the acoustic simulation and classification of the sources of noise in machinery are presented as well. In the conclusion, useful noise reduction tools are proposed in order to eliminate acoustic risks.
\end{abstract}




\section{Introduction}

Organizations of various types and sizes have to face a variety of external and internal factors (including physical factors, such as noise) and influences that cause uncertainty whether and when they will be able to meet their targets (e.g. high level of safety and health at work). The effect that this uncertainty has on the organization's objectives constitutes a risk.

Organizations manage risk in the following manner: they identify it, analyze it and then assess whether it should be modified to meet the established criteria, in order to achieve an acceptable level of risk. The process of risk management as a part of the safety analysis may be applied to different areas and levels, as well as specific functions, projects and activities. Although risk management practices have evolved over a long time, and for many areas had to meet different requirements, the adoption of consistent processes within the overall safety analysis can help to ensure that risk is managed effectively and efficiently. It is important to find and set policies and instructions for management of risks of any kind, scale and context in a systematic, transparent and credible manner. Each specific area and each application of risk management entails individual needs, specific stakeholders, specific perceptions and criteria. Therefore, a key task is to summarize all relations created within an activity at the beginning of the risk management process [2]. The implementation and maintenance of risk management allows the company to: - increase the likelihood of achieving its objectives, - promote proactive management,

- be aware of the need for identifying and addressing risks throughout the entire organization,

- improve risk identification,

- comply with relevant legislative requirements and international standards,

- improve communication and continuous learn-

ing,

- establish a sound basis for decision making and planning,

- improve surveillance,

- effectively allocate and use resources to handle risk,

- increase the operational efficiency and effectiveness,

- improve the health and safety performance, as well as environmental protection,
- improve loss prevention, and

- improve organizational flexibility.

The success of risk management depends on the effectiveness of management structure that provides the basis and regulations to be implemented across all levels of organization. The structure ensures that information about a risk obtained from the process of risk management is appropriately communicated and used as a basis for decisionmaking and accountability at all levels of the organization concerned [2].

\section{Safety Analysis as a Part of Risk Management}

Safety analysis is the basic method of learning about objects and phenomena in the process of risk management. It is the process in which the observed object is analyzed as a set of individual parts (elements, features, components, and properties) and mutual relations are sought between the parts, between each part and the whole and possibly even between the analyzed entity and other entities.

It allows:

- gaining the essential data on the phenomenon in question,

- uncovering the structure of entities and phenomena, and

- it serves to reveal the relationships between the elements (entities).

The safety analysis of an object comprises a vast analytical and synthetic activity performed before making a decision on the safety and health protection, assessment of the effectiveness and efficiency of all existing methods of risk assessment and the preparation of documents for elimination or prevention of risk. It includes a description of the object, a list and description of the relevant threats, possible ways of their elimination, and the definition of the object's risks.

Each of these activities is important when analyzing a particular object, and contributes to a better development of the system of safety and utilization of its elements. The analysis may cover both tangible and intangible assets.

Risk Management, Figure 1, involves the use of logical and systematic methods [8] for:

- communication and consultation within this process,

- establishing the context for identifying, analyzing, evaluation, and treatment of risks associated 
with an activity, process, function or product,

- monitoring and reviewing risk,

- reporting the results.

Risk assessment is a part of risk management which determines how the objectives can be affected, and analyzes the risks in terms of their likelihood and consequences before deciding whether further elimination is needed.

Risk assessment addresses these fundamental questions [8]:

-What may happen and why (according to the identification of risk)?

-What are the consequences?

-What is the probability of their future occurrence?
- Are there any factors that mitigate the consequences of the risk or reduce its likelihood?

Is the level of risk acceptable?

\section{Procedure for Designing Safe (low-noise) Machinery}

The process of designing safe (low-noise) machinery can be divided into 4 stages (product idea, conceptual design, design and description, and development of a prototype). The gained information related to individual phases enables categorization of potential threats with regard to their specific design criteria and elimination of risks (low noise level) [7].

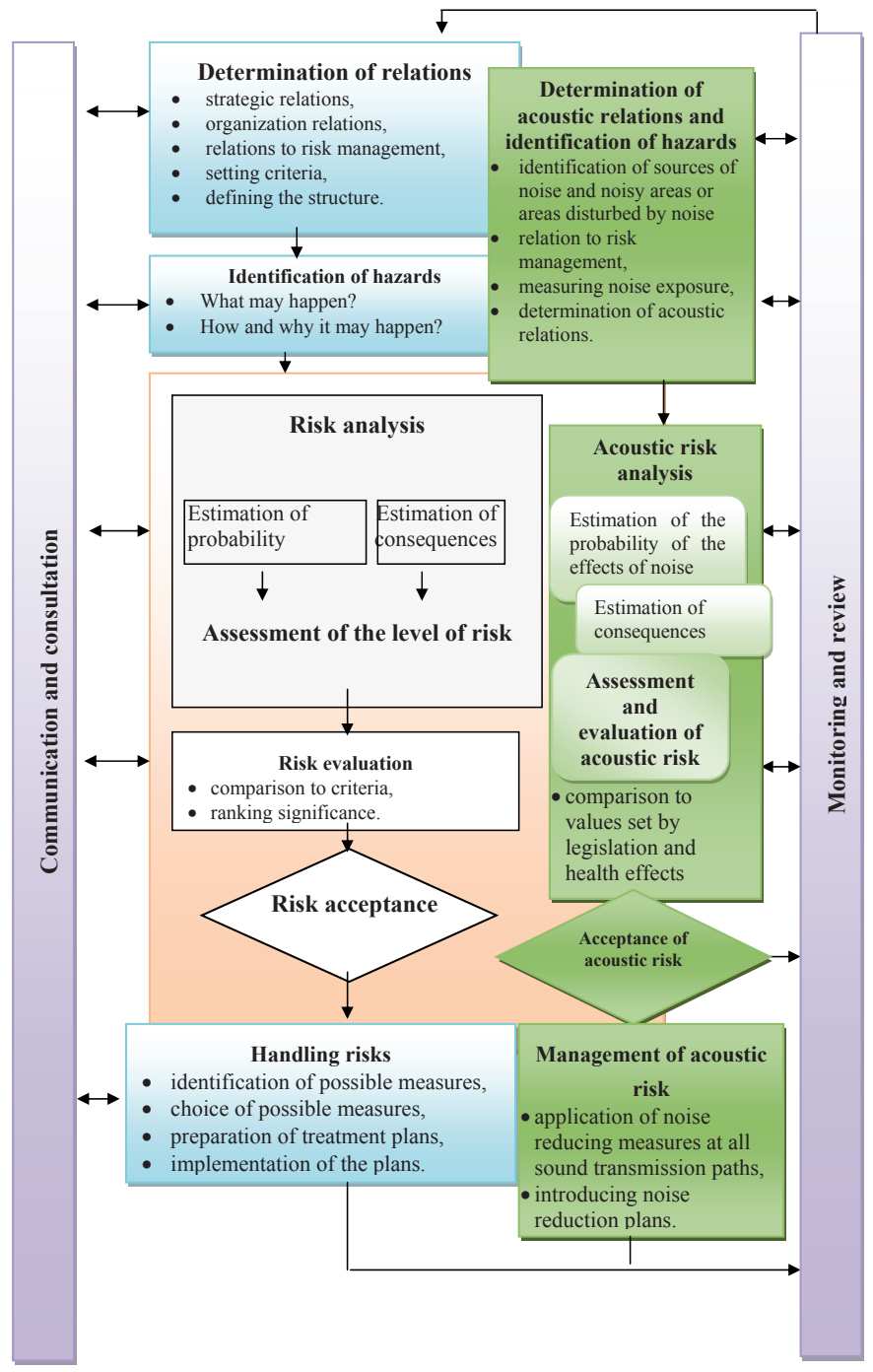

Fig. 1: Risk management process. 
Stage 1: Product idea - a list of requirements is created, which is a crucial document for the entire design task. The list includes technical requirements with reference to legislation, current status, competitive products, and customer requirements or reduced machine noise load as a selling point.

Stage 2: Conceptual design - this stage focuses mainly on achieving the required objectives. At this stage, there is little information about the final product and the noise parameters are often determined by comparison with solutions that are currently known.

Stage 3: Design and description - a quantitative estimate of the noise parameters is performed by selecting options and proposals.

Stage 4: Development of a prototype - the measurements performed on the prototype allow for quantification of the main sources of noise and sound paths. This may indicate specific measures leading to changes in the design. Compliance with the requirements will be verified by measurements.

The following procedure may be applied in each of the four stages described above. It is essential to adhere to the methodology of eliminating the major problems caused by noise at the earliest possible stage of machinery design [4]:

- the first step involves identifying of the main sources of machine noise and generating a list of priorities,

after detecting the main sources of noise, a more detailed analysis of noise mechanisms has to be conducted,

- the next step requires analyzing and describing the direct noise emission from its sources towards the recipient and the transmission of noise to the emitting surfaces,

- the final step is the analysis of noise emitted from these surfaces and the specification of various contributions to the sound pressure level at the recipient's location,

- evaluation of the most appropriate combination of measures for monitoring and minimization of noise.

When designing low-noise machinery the basic acoustic mechanisms should be identified, Figure 2.

\section{Practical Example of Acoustic Modelling and Classification of Machine Noise Sources}

Figure 3 shows a hydraulic system, which con- tains the following active noise components: electric motor, hydraulic pump and valve. They are all connected with the tank in a closed circuit. The hydraulic system contains active noise sources, i.e. sources from which noise is transmitted by air, fluid and construction. The transfer of noise from different sources of noise of the machine is shown in Figure 4. The sources of noise, paths and surfaces are listed in Tables 1 to 4 [7].

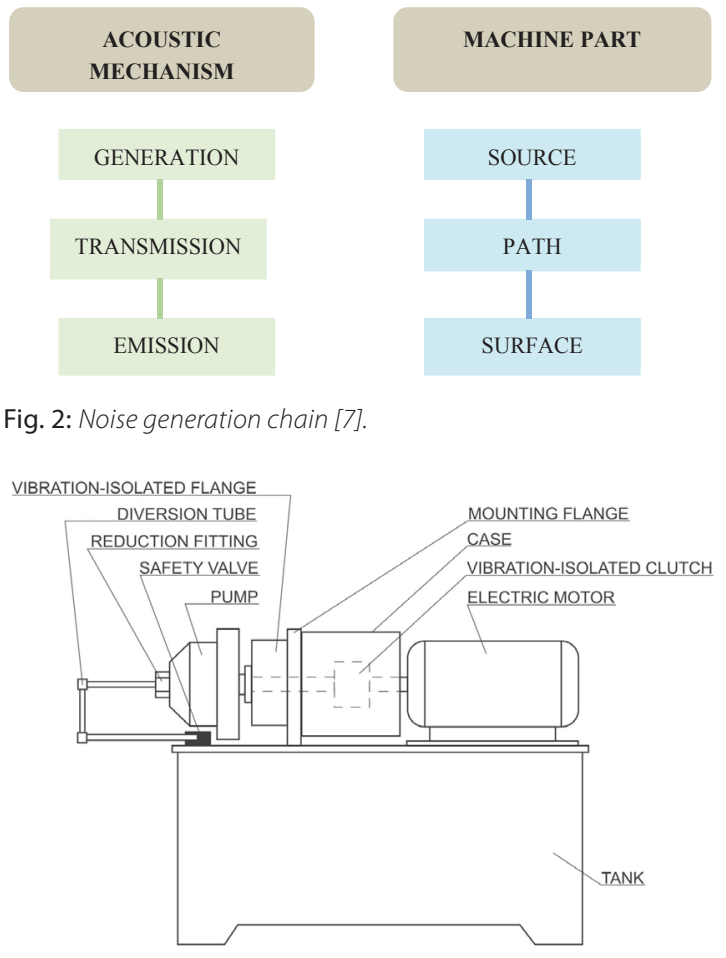

Fig. 3: Hydraulic system [7].

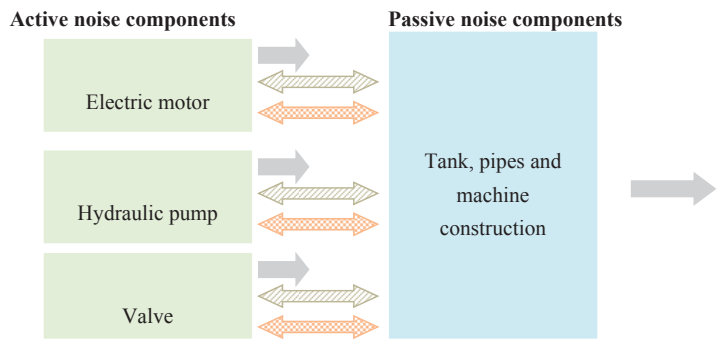

Fig. 4: Acoustic model of the hydraulic system.

Legend: $\Rightarrow$ noise transmitted by air, $\Longleftrightarrow$ noise transmitted by fluid, $\longleftrightarrow$ noise transmitted by construction. 
Table 1: Hydraulic system, sources of noise [7].

\begin{tabular}{|l|l|l|l|l|}
\hline COMPONENT & SOURCE & A & C & F \\
\hline Electric motor & Magnetic field & & - & \\
\hline & Ventilator & + & & \\
\hline & Unbalance & & - & \\
\hline Hydraulic pump & Pumping & & + & + \\
\hline & Unbalance & & - & \\
\hline Safety valve & Limited flow & & & - \\
\hline & Instability of the valve & & - & - \\
\hline
\end{tabular}

Table 2: Hydraulic system, transmission paths [7].

\begin{tabular}{|l|l|l|l|l|}
\hline COMPONENT & SOURCE & A & C & F \\
\hline Electric motor & Joints & & + & \\
\hline & Shaft & & - & \\
\hline Hydraulic pump & Joints & & + & \\
\hline & Shaft & & - & \\
\hline Safety valve & Fluid connectors & & - & \\
\hline & Joints & & - & \\
\hline Connections & Fluid connectors & & - & \\
\hline Pipes & Connecting elements & & + & \\
\hline & Steel pipes & & - & \\
\hline Tank & Fluid & & & - \\
\hline & Joints & & + & \\
\hline & Plates & & - & \\
\hline & Fluid & & & - \\
\hline
\end{tabular}

Table 3: Hydraulic system, emitting surfaces [7].

\begin{tabular}{|l|l|l|l|l|}
\hline COMPONENT & SOURCE & A & C & F \\
\hline Electric motor & Casing & + & & \\
\hline Hydraulic pump & Casing & - & & \\
\hline Pipes & Sides & - & & \\
\hline Tank & Sides & + & & \\
\hline
\end{tabular}

\section{Legend:}

A - noise transmitted by air

+ major contribution

$\mathrm{C}$ - noise transmitted by construction

- minor contribution

F - noise transmitted by fluid
Table 4: Hydraulic system; the effect of monitoring and noise reducing measures [7].

\begin{tabular}{|l|l|l|}
\hline \multicolumn{2}{|l|}{$\begin{array}{l}\text { Monitoring and reduction of noise from } \\
\text { hydrostatic system 1500 rpm, } 180 \text { bar }\end{array}$} & LwA (dB) \\
\hline 1 & $\begin{array}{l}\text { All transmission routes are shown } \\
\text { in Figure 4 - Acoustic model of the } \\
\text { hydraulic system }\end{array}$ & 90 \\
\hline 2 & $\begin{array}{l}\text { A separate frame supporting the } \\
\text { motor and the hydraulic pump are } \\
\text { suspended beneath the container lid } \\
\text { with vibration insulators. The reducti- } \\
\text { on of structure-borne sound transmis- } \\
\text { sion towards the machine construc- } \\
\text { tion resulted in a small reduction of } \\
\text { acoustic power. }\end{array}$ & 89 \\
\hline 3 & $\begin{array}{l}\text { The engine and frame are separated } \\
\text { from the tank. Connection between } \\
\text { the pump and the valve is provided } \\
\text { by a 2 m long hydraulic hose. This step } \\
\text { brings a further reduction of 3 dB as } \\
\text { a result of decreased transfer by the } \\
\text { construction towards the tank. }\end{array}$ & 86 \\
\hline 4 & $\begin{array}{l}\text { The hydraulic pump is mounted on } \\
\text { the conical flange of the electric mo- } \\
\text { tor which contains a vibration isolator. } \\
\text { The fan is removed from the electric } \\
\text { motor and cooling is provided by wa- } \\
\text { ter. This step reduces noise by 1 dB. }\end{array}$ & 85 \\
\hline 5 & $\begin{array}{l}\text { Finally, the electric motor is closed to } \\
\text { reduce the transmission of noise from } \\
\text { its surface by air. }\end{array}$ & 81 \\
\hline
\end{tabular}

Numerous experiments were carried out to identify various noise sources and paths and noise emitting surfaces. The main results are shown in the above table as measurements of acoustic power in a reverberation chamber.

The findings resulting from the experiments are as follows:

- the level of sound pressure emitted from the surface of the hydrostatic pump itself and transmitted by air was $9 \mathrm{~dB}$ lower than the acoustic performance of the complete system,

- the main sources of noise were the noise contributions transmitted by the construction and by the hydrostatic pump fluid,

- the dominant emitting surfaces are those of the electric motor of the tank.

\section{Conclusion}

Measurements conducted on the prototype 
allow for the detection of the main sources of noise and specific measures that lead to structural changes in the stages of detailed design and concept.

The first step involves the hazard analysis by means of measurements aimed at detecting [7]:

a the main sources of noise and determining their classification,

noise transmission paths from the source to the receiver or through the construction towards the emitting surface,

- parts of the machine that emit noise (openings, plates).

In general, the analysis begins with relatively simple procedures leading to a rough identification of noise sources and their spatial, temporal and spectral classification. More detailed analyses associated with the assessment of noise sources as hazards and the assessment of transmission paths are performed on selected parts of the machine.

The assessment of the detected noise sources involves listing the major sources. In this process, noise sources are determined and their essential characteristics are recorded (sound power, sound pressure level at the reference measurement point, time function, frequency spectrum, and position within the machinery).

When planning measures aimed at monitoring and reduction of noise for partial noise sources, in order to reduce the overall level, a considerable number of special properties must be taken into account [6]:

- It is not necessary to completely eliminate the dominant noise source, since the total noise will be determined by the remaining noise sources. In general, it is sufficient to reduce the dominant component to approximately $5 \mathrm{~dB}$ below the residual noise. Further influences of this partial noise source have only minor effects on the overall noise level,

- If there are several partial noise sources which are approximately the same, measures for monitoring and reduction of noise have to be applied to all such sources. The reduction of individual noise sources will have only a marginal effect on the overall noise level,

- The abovementioned relationships apply only to partially incoherent noise sources, i.e. sources that do not have the same source of excitation.

The goal of noise monitoring and reduction measures is to reduce noise emissions from par- tial noise sources according to the priorities determined in the risk assessment. The partial noise sources comprise an inner source, the transmission path and noise emitting parts of the machine, therefore, all three components may interact. [3]

For partial noise sources, in some circumstances, it may be necessary to determine several actual interactions with respect to the excitation, transmission or emission (sub-equilibrium), to identify the internal sources of noise and take measures in all three steps of noise generation.

In general, measures to monitor and eliminate noise are most effective when carried out near the internal source. In principle, the final degree of sound power reduction results from the minimization of noise at:

- the internal source of noise,

- the transmission structure, and

at the emitting parts of the machine.

In practice, the method may be combined with technological and economic requirements. [5]

The objective of the final evaluation is to verify the achieved level of noise emitted by the observed machinery. This evaluation involves measurement of the parameters set before the start of work on the proposal. Measuring methods for determining the sound power of machines are prescribed in international standards and test procedures for determining noise for specific machines. In addition, further measurements of sound pressure they can be carried out at specific positions.

During the final examination, the machine has to:

\section{- be operated with specific accessories,}

- have the operating parameters set according to the list of requirements for the design, and

a be isolated from other components (e.g. connected lines or pipelines, which also emit noise).

\section{Acknowledgments}

This contribution is the result of the project Research of Integrated Risk Research into new and newly emerging risks of industrial technologies within integrated safety as a precondition for management of sustainable development, Nr. APVV $0337-11$.

\section{References}

[1] Dietz, P., Gummersbach, F.: Lärmarm konstruieren XVIII, Systematische Zusammenstellung maschinen-akustischer 
Konstruktionsbeispiele, Berlin, 2000, ISSN 1433-2086.

[2] Hofreiter, L. 2002. Bezpečnostný manažment. Žilina: EDIS Žilinská univerzita, 1. vydanie, 2002, 178 s. ISBN 80-7100953-9.

[3] Schirmer, W.: Lärmbekämfung. Verlag Tribüne, Berlin, 1989.

[4] STN EN ISO 11690-1 (01 1651) Akustika. Odporúčané postupy na navrhovanie nízkohlučných pracovísk vybavených strojovými zariadeniami. Čast' 1: Stratégia znižovania hluku, Slovenský ústav technologickej normalizácie, Bratislava 1999.

[5] STN EN ISO 11690-2 (01 1651) Akustika. Odporúčané postupy na navrhovanie nízkohlučných pracovísk vybavených strojovými zariadeniami. Čast’ 2: Opatrenia na znižovanie hluku, Slovenský ústav technologickej normalizácie, Bratislava 1999.

[6] STN EN ISO 11690-3 (01 1651) Akustika. Odporúčané postupy na navrhovanie nízkohlučných pracovísk vybavených strojovými zariadeniami. Čast' 3: Šírenie zvuku a predpovedanie hluku na pracovisku, Slovenský ústav technologickej normalizácie, Bratislava 1999.

[7] STN EN ISO 11688-1 (01 1649) Akustika. Odporúčané postupy na navrhovanie nízkohlučných strojov a zariadení. Čast' 1: Plánovanie, Slovenský ústav technologickej normalizácie, Bratislava 2009.

[8] STN ISO 31000 (01 0381) Manažérstvo rizika. Zásady a návod. Slovenský ústav technologickej normalizácie, Bratislava 2011.

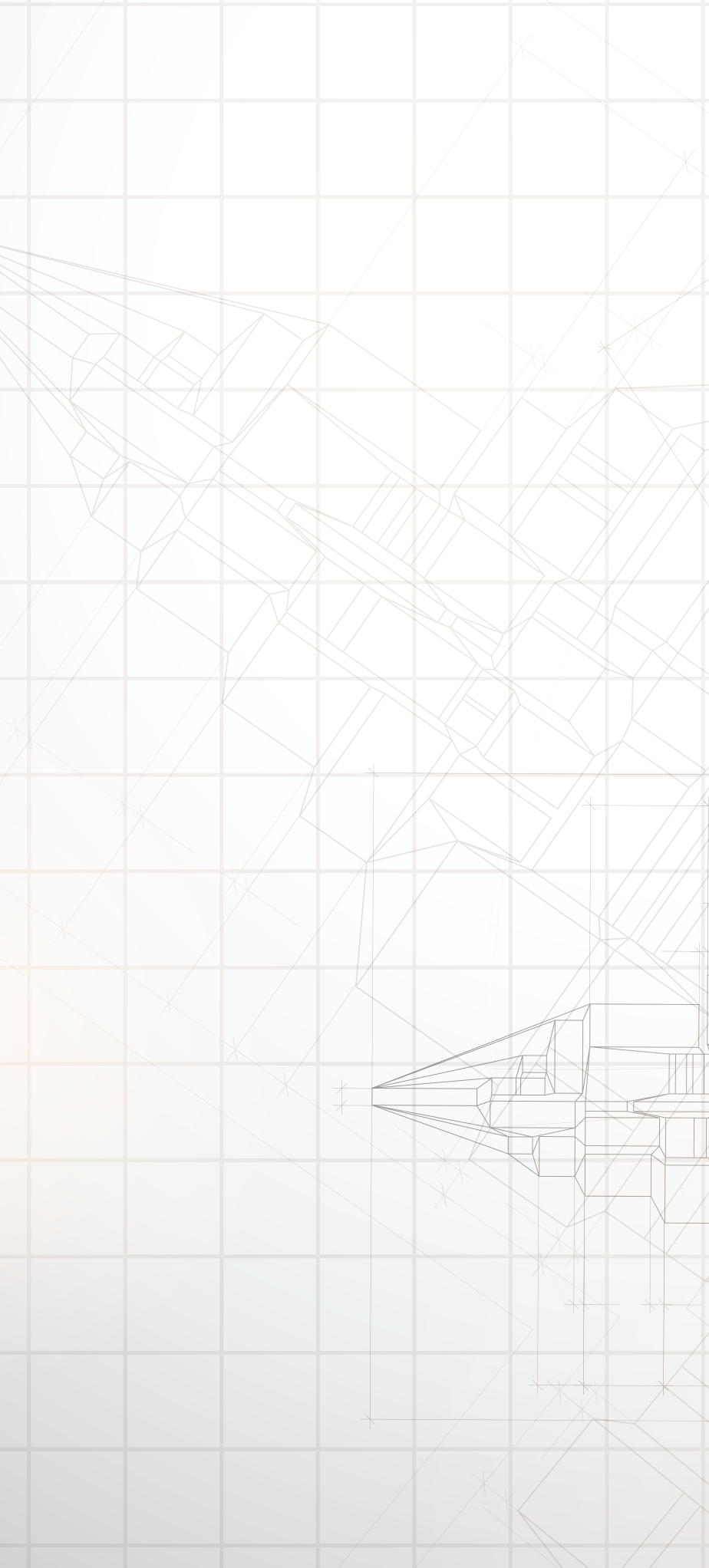




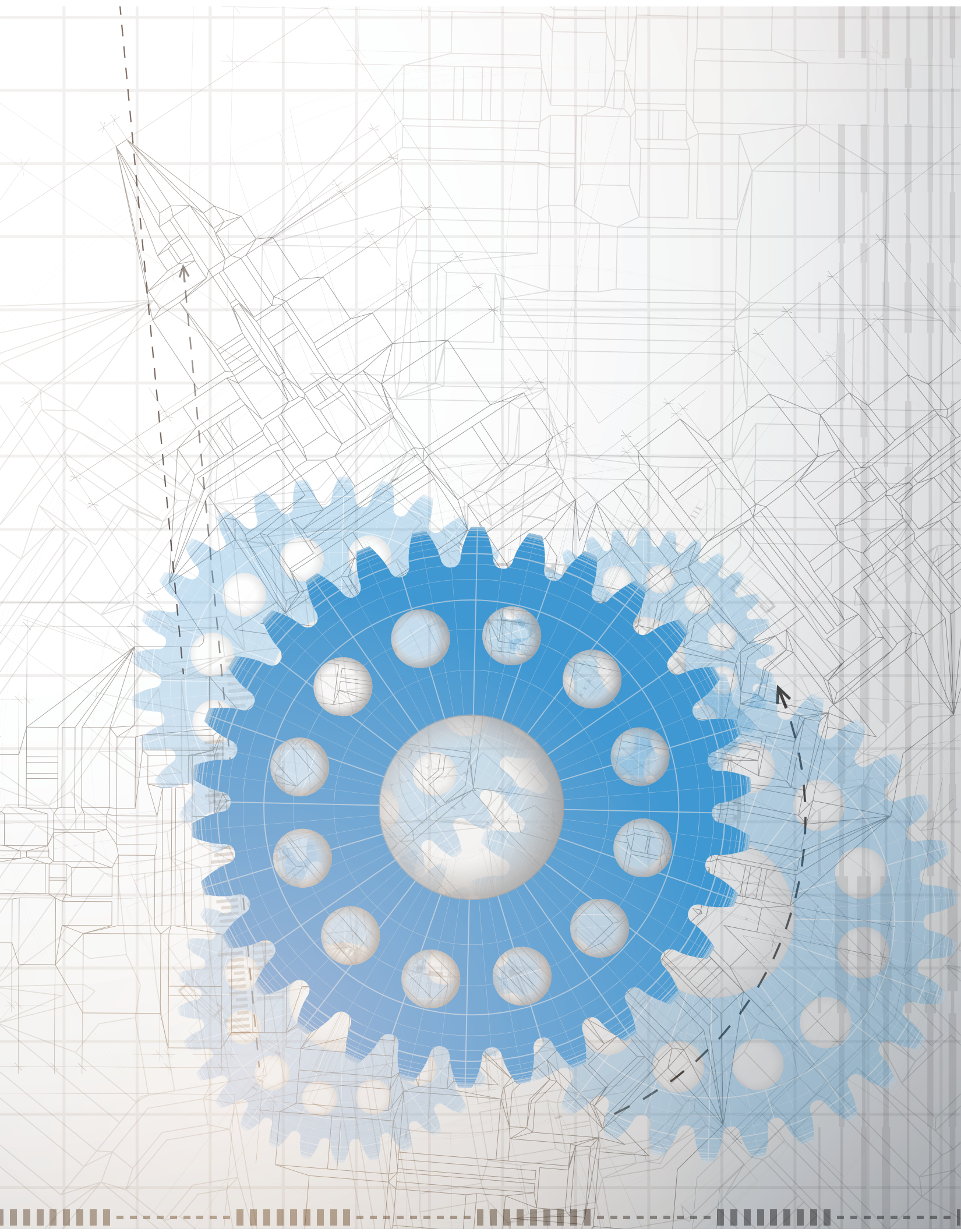

